\title{
Variability in Growth and Yield Attributes among Different Growth Habits of Groundnut Genotypes
}

\author{
P. Sreelatha ${ }^{*}$, P. Sudhakar, V. Umamahesh, D. Subramanyam and R.P. Vasanthi \\ Department of Crop Physiology, S.V. Agricultural College, Tirupati-517502, A.P, India \\ *Corresponding author
}

\section{Keywords \\ CGR, LAI, plant height, total dry matter, growth habit \\ Article Info \\ Accepted: \\ 10 May 2019 \\ Available Online: \\ 10 June 2019}

\section{Introduction}

The groundnut (Arachis hypogaea L.) is one of the major oilseed crops of the country, but its production and productivity needs to be significantly enhanced to meet the national shortage of availability of edible oil in India. India is the second largest producer of groundnut after Brazil, accounting for 40.68 lakh ha of the total area and 66.15 lakh tonnes and productivity of $1626 \mathrm{~kg} \mathrm{ha}^{-1}$ in Kharif season. Andhra Pradesh ranks second both in area (6.48 lakh ha) and production (8 lakh tonnes) with an average productivity of 1238 $\mathrm{kg} \mathrm{ha}^{-1}$. Growing of groundnut in kharif is gaining importance in Southern Agro-climatic zone of Andhra Pradesh.

The productivity of plants reflects the degree of accumulation of photosynthates and their partitioning measured by harvest index. Groundnut crop is characterised by indeterminate growth habit where growth and development of reproductive and vegetative organs overlap. This leads to inter organ competition for photosynthates and metabolites. Differences in partitioning of assimilates between vegetative and reproductive parts, length of the pod filling period and the rate of fruit establishment are three important physiological processes and difference in these explain variation in yield amongst groundnut cultivars (Duncan et al., 1978).

Orientation of leaves in plant canopy plays a decisive role in the radiation penetration, which influence the canopy photosynthesis and hence the crop productivity. The dry 
matter production of many crops has been linked with light interception and radiation use efficiency. Hence in rainfed conditions, knowledge of the inter relationship among canopy orientation, growth attributes and yield potentiality of this crop is a research priority. The information generated is valuable for breeders in designing and breeding groundnut ideal plant types for rainfed situations.

\section{Materials and Methods}

An experiment was conducted at S.V. Agricultural College, Tirupati, during kharif, 2017 and 2018 on sandy loam soil. 10 spanish bunch genotypes with three growth habit types Erect type viz., TCGS894, K6, TAG24, TMV2, Narayani; decumbent-2 type viz., kadiri amaravathi, K9; Decumbent-3 type viz., TCGS1157, ICGS76, Dharani were laid out in randomized block design with three replications.

Observations on plant height, total dry matter, leaf area, leaf area index, crop growth rate and pod yield after harvest were recorded with15 days interval.

\section{Statical analysis}

The data analysis was performed with SAS 16.0 software. Data were subjected to Fishers method of analysis of variance using the GLM procedure of SAS as described by Gomez and Gomez. The differences of means were identified by Duncan's univariate test at significant level of $5 \%$.

\section{Results and Discussion}

\section{Leaf area $\left(\mathrm{cm}^{2}\right.$ plant $\left.^{-1}\right)$}

Leaf area the number of leaves and leaf area are important in determining the size of photosynthetic system (Lopez et al., 1994).
Among all the genotypes D-2 type kadiri Amaravathi recorded highest leaf area $\left(1722.10 \mathrm{~cm}^{-2}\right.$ plant $\left.^{-1}\right)$ it was on par with D-3 type TCGS 1157(1719.14 $\mathrm{cm}^{-2}$ plant $\left.^{-1}\right)$ at 60 DAS. TCGS1157 was on par with other D-3 type ICGS $76\left(1548.11 \mathrm{~cm}^{-2}\right.$ plant $\left.^{-1}\right)$. ICGS76 was on par with dharani (1305.39 $\mathrm{cm}^{-2}$ plant $\left.^{-1}\right)$. TCGS894 (838.84 $\mathrm{cm}^{-2}$ plant $\left.^{-1}\right)$, TAG24 (940.10 $\mathrm{cm}^{-2}$ plant $^{-1}$ ) recorded lowest leaf area however there was no significant difference between TCGS894 and TAG24 genotypes.

From the mean values it was evident that among three growth habits decumbent-2 recorded highest leaf area $\left(1530.30 \mathrm{~cm}^{-2}\right.$ plant $\left.^{-1}\right)$, followed by decumbent-3 (1524.11 $\mathrm{cm}^{-2}$ plant $^{-1}$ ) followed by erect type of growth habit $\left(1189.08 \mathrm{~cm}^{-2}\right.$ plant $\left.^{-1}\right)$ at 60 DAS. However at harvest D-3 type maintained higher green leaf area compared to other two growth habit types.

D-3 and D-2 growth habit type genotypes recorded higher leaf area along with number of primary and secondary branches.

Photosynthetic capacity of the plant is a function of leaf area development which could be probably due to increased assimilatory surface at all subsequent growth stages reported by Borkar and Dharanguttikar (2014) in groundnut (Mane et al., 2017).

\section{Plant height (cm)}

Erect type Narayani recorded highest plant height $(53.32 \mathrm{~cm})$ followed by D-3 type dharani $(48.90 \mathrm{~cm})$ however there was no significant difference between narayani and dharani. K6 (44.25cm), TMV2 (42.02cm) K9 $(43.07 \mathrm{~cm})$ recorded moderate and on par values for $\mathrm{p}$ plant height. Lowest plant height was recorded by TCGS $1157(26.39 \mathrm{~cm})$ it was on par with TCGS 894(29.34cm), TAG24 $(29.89 \mathrm{~cm})$, Kadiri amaravathi $(29.28 \mathrm{~cm})$. 
Among three growth habits erect type showed highest mean plant height $(39.76 \mathrm{~cm})$ followed by Decumbent-2 growth habit $(36.18 \mathrm{~cm})$, decumbent-3 $(36.64 \mathrm{~cm})$. This was corroborated with Bhagavatha priya et al., 2016 they reported that K6 (erect) recorded highest Plant height $(44.3 \mathrm{~cm})$.

Several workers reported a negative correlation between plant height and pod yield in groundnut. Less plant height with the larger number of pegs located in the lower third of the plant (Lakshmaiah et al., 1983, Santos et al., 1997, Mallikarjuna et al., 2003) having greater the efficiency in forming fruits (Santos et al., 2000).

\section{Total drymatter production (g plant-1)}

Under field conditions selection for high biomass production might reflect high WUE (Roy Stephen, 1995). Positive relation between total plant dry matter and WUE was documented by several scientists (Hubick et al., 1988; Latha and Reddy, 2007).

All the three genotypes of dcumbent-3 growth habit viz., TCGS 1157 (52 g plant-1) followed by Dharani (45.55 g plant-1), ICGS 76(44.31 g plant-1), however there was significance difference between dharani and ICGS 76 . Moderate total dry matter was recorded in decumbent-2 growth habit viz., kadiri amaravathi (40.67 g plant $\left.{ }^{-1}\right)$, K9 (38.23 g plant-1), followed by erect growth habit narayani (35.64 g plant $\left.{ }^{-1}\right)$, K6 (35.42 g plant $^{-1}$ ), however above four varieties were not significantly differed. Lowest dry matter was recorded by erect types viz., TCGS 894, TAG 24. D-3 and D-2 posses wider the primary branch angle which lead to high light interception and higher dry matter accumulation per unit amount of radiation interception and higher the rate of photosynthesis. Similar results were recorded by Dapaah et al., (2014) Virginia (spreading) cultivars had slightly higher TDM after 60 DAP, which produced higher number of branches per plant than bunch type cultivars therefore, might have larger and faster canopy formation and spread enabling them to intercept more solar radiation necessary for photosynthesis thus contributing to more TDM accumulation.

Mean values of erect, D-2, D-3 growth habits revealed that D-3 showed highest total dry matter (48.14 g plant $\left.{ }^{-1}\right)$, followed by D-2 (39.45 $\left.\mathrm{g} \mathrm{plant}^{-1}\right)$ and erect (32.35 $\left.\mathrm{g} \mathrm{plant}^{-1}\right)$. Mane et al., (2017) also concluded that virginia type genotype (AK 303) recorded highest total dry matter production $(30.63 \mathrm{~g}$ plant-1).

\section{Crop growth rate $\left(\mathrm{g} \mathrm{m}^{-2} \mathrm{day}^{-1}\right)$}

Crop growth rate (CGR) was increased up to 45-60 DAS and gradually decreased till harvest irrespective of genotypes. All genotypes showed significant differences at all growth stages except $15-30$ and 30-45 DAS. Among the varieties D-3 growth habit genotypes recorded highest CGR viz., Dharani (38.19 $\mathrm{g} \mathrm{m}^{-2} \mathrm{day}^{-1}$ ) and TCGS 1157 (36.38 $\mathrm{g} \mathrm{m}^{-2}$ day $^{-1}$ ) followed by D-2 growth habit genotypes kadiri amaravthi (30.76 g m-2 day-1), K9 (23.65 $\mathrm{g} \mathrm{m}^{-2}$ day $\left.^{-1}\right)$ and erect TAG24 (23.46 $\mathrm{g} \mathrm{m}^{-2}$ day $\left.^{-1}\right)$. Lowest total dry matter was recorded in erect genotypes viz., TCGS894 (21.21 $\mathrm{g} \mathrm{m}^{-2}$ day $\left.^{-1}\right)$, Narayani (26.16 $\mathrm{g} \mathrm{m}^{-2}$ day $^{-1}$ ).

Mean values of all three growth habits revealed that D-3 growth habit recorded highest CGR (33.41 $\mathrm{g} \mathrm{m}^{-2}$ day $^{-1}$ ), followed by D-2 (26.79 $\left.\mathrm{g} \mathrm{m}^{-2} \mathrm{day}^{-1}\right)$ and erect growth habit $\left(23.09 \mathrm{~g} \mathrm{~m}^{-2}\right.$ day $\left.^{-1}\right)$ and hence similar trend was recorded in dry matter accumulation. Mane et al., (2017) revealed that virginia type genotype (AK 303) recorded highest CGR at vegetative growth (0.356 g/day) similary Reshma (2014) reported higher CGR for D-3 
growth habit genotypes Dharani $\left(28.54 \mathrm{~g} \mathrm{~m}^{-2}\right.$ day $\left.^{-1}\right)$ TCGS $1157 \quad\left(22.28 \quad \mathrm{~g} \mathrm{~m}^{-2} \quad\right.$ day $\left.^{-1}\right)$ compared to other genotypes.

\section{Leaf area index}

Leaf area index (LAI) showed increasing trend up to 60 DAS and there after gradually decreased irrespective of genotypes. All varieties significantly differed for LAI at all growth stages of the crop period. Among the all genotypes D-2 type kadiri amaravthi recorded highest LAI (5.39) followed by D-3 type TCGS 1157 (5.24) it was on par with ICGS76 (4.75) and TMV2 (4.74). Lowest LAI recorded in TCGS894 (2.58) TAG 24 (2.94), however there was no significance difference between TCGS 894 and TAG 24.

Reshma (2014) also reported increase in LAI up to 60 DAS and thereafter declined up to harvest in all the groundnut genotypes. D-3 type genotypes TCGS $1157 \quad$ (3.26) Dharani(3.78) recorded higher CGR values compared to all other genotypes tested.

Mean values of three growth habits revealed that D-3 growth habit sowed highest LAI (4.81) followed by D-2 (4.73) and erect growth habit types recorded lowest LAI (3.62). Gardner and Auma (1989) also reported that higher LAI was observed for florunner (spreading) compared to bunch type groundnut. Kiniri et al., (2004) revealed that highest leaf area index in spreading type of groundnut genotype florunner (7.54).

Leaf area index (LAI) describes the size of assimilatory apparatus of a crop or the crop canopy expansion. Duncan et al., (1978) reported that maximum light interception occurred when the LAI was three. Maintenance of high LAI is advantageous especially in Kharif season due to low photosynthetic rate under low light conditions. The D-3 and D-2 genotypes with higher LAI are more adoptable to kharif low light conditions.

\section{Pod yield (kg ha $\left.{ }^{-1}\right)$}

All genotypes were significantly differed for pod yield D-3 type TCGS 1157 recorded highest pod yield of $3760.77 \mathrm{~kg} \mathrm{ha}^{-1}$ it was on par with D-2 type kadiri amaravthi (3653.05 $\left.\mathrm{kg} \mathrm{ha}^{-1}\right)$. Kadiri amaravthi showed on par results with other D-2 type K9 $(3334.45 \mathrm{~kg}$ $\mathrm{ha}^{-1}$ ) and D-3 type Dharani (3410.14 $\mathrm{kg} \mathrm{ha}^{-1}$ ). Lowest pod yields was recorded by erect genotypes, however there was no significant difference among those varieties viz., TCGS $894\left(2550.14 \mathrm{~kg} \mathrm{ha}^{-1}\right)$, TAG24 $(2631.46 \mathrm{~kg}$ $\mathrm{ha}^{-1}$ ), K6 (2435.07), TMV2 (2389.59 kg ha-1), Narayani $\left(2459.03 \mathrm{~kg} \mathrm{ha}^{-1}\right)$.

The data reveals that mean values of decumbent-3 growth habit genotypes recorded highest pod yield (3465.53 $\left.\mathrm{kg} \mathrm{ha}^{-1}\right)$, followed by decumbent-2 (3493.75 $\left.\mathrm{kg} \mathrm{ha}^{-1}\right)$ and erect growth habit $\left(2493.06 \mathrm{~kg} \mathrm{ha}^{-1}\right)$. This is due to decumbent-3 growth habit genotypes having wider angle between primary branch and main stem due to this more light was intercepted and accumulate high dry matter per unit light interception.

Dry matter portioning to pod was more in decumbent-3 growth habit. Similar results were reported by Gardner and Auma (1989). They observed that more pod yield $3.36 \mathrm{Mg}$ $\mathrm{ha}^{-1}$ in spreading type of groundnut cultivars when compared with bunch type $(2.4 \mathrm{Mg}$ $\mathrm{ha}^{-1}$ ) of groundnut cultivars

The genotypes ICG-8029 and ICG-8428 recorded the highest dry pod yield may be due to photosynthetic rate, dry matter accumulation, chlorophyll content (Dharanguttikar and Borkar, 2014), TCGS 1157 (decumbent-3) showed Pod yield (3686.5 $\mathrm{kg} \mathrm{ha}^{-1}$ ) (Saikat et al., (2017) (Table 1). 
Table.1

\begin{tabular}{|c|c|c|c|c|c|c|c|}
\hline & & $\begin{array}{l}\text { Plant } \\
\text { height }\end{array}$ & Leaf area & $\begin{array}{l}\text { Crop } \\
\text { growth } \\
\text { rate }\end{array}$ & $\begin{array}{l}\text { Total } \\
\text { dry } \\
\text { matter }\end{array}$ & $\begin{array}{l}\text { Leaf area } \\
\text { index }\end{array}$ & $\begin{array}{l}\text { Pod yield } \\
\left(\mathrm{kg} \mathrm{ha}^{-1)}\right.\end{array}$ \\
\hline & Erect & & & & & & \\
\hline 1. & TCGS 894 & $29.34^{\mathrm{D}}$ & $838.84^{\mathrm{E}}$ & $21.21^{\mathrm{C}}$ & $30.42^{\mathrm{EF}}$ & $2.58^{\mathrm{E}}$ & $2550.14^{\mathrm{D}}$ \\
\hline 2. & TAG 24 & $29.89^{\mathrm{D}}$ & $940.10^{\mathrm{E}}$ & $23.46^{\mathrm{BC}}$ & $27.35^{\mathrm{F}}$ & $2.94^{\mathrm{E}}$ & $2631.46^{\mathrm{D}}$ \\
\hline 3. & K6 & $44.25^{\mathrm{B}}$ & $1214.94^{\mathrm{D}}$ & $31.45^{\mathrm{AB}}$ & $35.42^{\mathrm{CDE}}$ & $3.70^{\mathrm{D}}$ & $2435.07^{\mathrm{D}}$ \\
\hline 4. & TMV2 & $42.02^{\mathrm{B}}$ & $1547.10^{\mathrm{BC}}$ & $23.52^{\mathrm{BC}}$ & $32.92^{\mathrm{DEF}}$ & $4.74^{\mathrm{BC}}$ & $2389.59^{\mathrm{D}}$ \\
\hline \multirow[t]{3}{*}{5.} & Narayani & $53.32^{\mathrm{A}}$ & $1269.37^{\mathrm{D}}$ & $26.16^{\mathrm{C}}$ & $35.64^{\mathrm{DEF}}$ & $4.11^{\mathrm{D}}$ & $2459.03^{D}$ \\
\hline & Mean & 39.76 & 1189.08 & 23.09 & 32.35 & 3.62 & 2493.06 \\
\hline & Decumbent-2 & & & & & & \\
\hline 6. & K9 & $43.07^{\mathrm{B}}$ & $1338.50^{\mathrm{D}}$ & $23.65^{\mathrm{BC}}$ & $38.23^{\mathrm{CD}}$ & $4.08^{\mathrm{D}}$ & $3334.45^{\mathrm{B}}$ \\
\hline \multirow[t]{3}{*}{7.} & Kadiri Amaravathi & $29.28^{\mathrm{D}}$ & $1722.10^{\mathrm{A}}$ & $30.76^{\mathrm{AB}}$ & $40.67^{\mathrm{BC}}$ & $5.39^{\mathrm{A}}$ & $3653.05^{\mathrm{AB}}$ \\
\hline & Mean & 36.18 & 1530.30 & 26.79 & 39.45 & 4.73 & 3493.75 \\
\hline & Decumbent-3 & & & & & & \\
\hline 8. & Dharani & $48.90^{\mathrm{A}}$ & $1305.39^{\mathrm{CD}}$ & $38.19^{\mathrm{A}}$ & $45.55^{\mathrm{B}}$ & $4.25^{\mathrm{CD}}$ & $3410.14^{\mathrm{B}}$ \\
\hline 9. & TCGS 1157 & $26.39^{\mathrm{D}}$ & $1719.14^{\mathrm{AB}}$ & $36.38^{\mathrm{A}}$ & $52.00^{\mathrm{A}}$ & $5.24^{\mathrm{AB}}$ & $3760.77^{\mathrm{A}}$ \\
\hline \multirow[t]{3}{*}{10.} & ICGS 76 & $34.64^{\mathrm{C}}$ & $1548.11^{\mathrm{BC}}$ & $26.14^{\mathrm{BC}}$ & $44.31^{\mathrm{B}}$ & $4.75^{\mathrm{BC}}$ & $3030.56^{\mathrm{C}}$ \\
\hline & Mean & 36.64 & 1524.21 & 33.41 & 48.14 & 4.81 & 3465.53 \\
\hline & Total mean & 38.10 & 1344.36 & 28.09 & 37.86 & 4.18 & 2749.56 \\
\hline $\begin{array}{l}\text { LSD } \\
(P=0.05)\end{array}$ & & 0.001 & 0.0002 & 0.0001 & 0.0001 & 0.0001 & 0.0001 \\
\hline
\end{tabular}

In conclusion, growth analysis is one of the measures for accessing the seed yield of the plant. The physiological basis of yield difference can be measured through an evaluation of difference in growth parameters and their impact on yield. The productivity of crop may be related with the parameters such as CGR, LAI, NAR, RGR, SLA, LAR. The significant differences among the genotypes for total dry matter production, CGR, LAI at various stages of growth played an important role in yield determining processes. All growth attributes recorded significantly higher values in decumbent-3 types dharani and TCGS1157 compared to other genotypes. Due to high light interception avoidance of mutual shading and more dry matter accumulation per unit amount of light interception. Thus finally increases pod yield. Decumbent-3 growth habit type should to be advantageous over decumbent -2 and erect types among Spanish bunch genotypes increase the source sink relationship in groundnut.

\section{References}

AICRP on Groundnut, Annual Report, 2017 Bhagavatha Priya, T., Subramanyam, D., Sumathi, V and Naidu, M.V.S. 2016. Growth characters and yield of early Kharif groundnut as influenced by varieties and plant populations. IOSR Journal of Agriculture and Veterinary Science. 9 (5): 81-83.

Borkar, V.H and Dharanguttikar, V.M. 2014. Evaluation of groundnut (Arachis hypogaea L.) Genotypes for physiological Traits. International Journal of Scientific and Research. 
4(1): 1-8.

Dharanguttikar, V.M and Borkar, V.H. 2014. Physiological Analysis of Groundnut (Arachis hypogae L.) genotypes. International Journal of Scientific and Research. 4 (1):1-9.

Duncan, W.G. 1969. Cultural manipulation for higher yields. In R.C. Dinauer (ed.) Physiological aspects of crop yield. ASA, Madison, WI. 327-339.

Gardner, F.P and Auma, E.O. 1989. Canopy Structure, Light Interception, and Yield and Market Quality of Peanut Genotypes as Influenced by Planting Pattern and Planting Date. Field Crops Research. 20:13-29.

Kiniry, J.R., Simpson, C.E., Schubert, A.M., Reed, J.D. 2005. Peanut leaf area index, light interception, radiation use efficiency and harvest index at three sites in texas. Field crops research. 91: 297-306.

Lakshmaiah, B., Reddy, P.S and Reddy, B.M. 1983. Selection criteria for improving yield in groundnut (Arachis hypogaea L.). Peanut science. 38: 607-611.

Lopez, F.B., Johnson, C and Chouhan, Y.S. 1994. Effect of timing of drought stress on phenology, yield and yield components of short duration pigeon pea. Journal of Agronomy and Crop Science. 177: 311-320.

Mallikarjuna, S.B.P., Upadhyaya, H.D., Goudara, P.V.K and Kullaiswamya, B.Y. 2003. Phenotypic variation for agronomic characteristics in a groundnut core collection for Asia. Field Crops Research. 84: 359-370.

Mane V.A., Ladole, M.Y. Shinde, A.A and Bhuyar, A.R. 2017. Physiological Analysis of Growth and Yield Variation in Groundnut (Arachis hypogaea L.). Electronic Journal of Plant Breeding. 8(4): 1258 -1264.

Reshma, A. 2014. Studies on growth, drought tolerance and yield of groundnut genotypes (pre release and release) for early kharif situation. M.Sc. (Ag.) Thesis. Acharya N.G. Ranga Agricultural University, Hyderabad.

Santos, R.C., Moraes, J.S and Guimarães, M.B. 1997. Characters de floração e reprodução em genótipos de amendoim do tipo ereto, ramador e decumbente. Pesquisa Agropecuária Brasileira. 32: 1257-1262.

\section{How to cite this article:}

P. Sreelatha, P. Sudhakar, V. Umamahesh, D. Subramanyam and Vasanthi, R.P. 2019. Variability in Growth and Yield Attributes among Different Growth Habits of Groundnut Genotypes. Int.J.Curr.Microbiol.App.Sci. 8(06): 1066-1071.

doi: https://doi.org/10.20546/ijcmas.2019.806.131 